\title{
RELIGIOUS-MORAL TENETS IN THE SERMONS OF FATHER ARSENIE BOCA
}

\author{
Ph.D. Nicușor BELDIMAN, \\ "Faculty of Orthodox Theology ,Justinian Patriarch", \\ University of Bucharest, \\ ROMANIA, \\ E-mail: prnbeldiman@gmail.com
}

\begin{abstract}
The present paper is centred on one of the outstanding figures of 20th-century Romanian preaching: Father Arsenie Boca, a great spiritual director, greatly revered by the Romanian people both in his lifetime and today, and a victim of communist persecutions. A brief biography is followed by a synthetic presentation of the religious-moral tenets put forth in his sermons: the Christian outlook on life (balance; attitude towards life; decision making; true freedom; the vice of idleness; rules to be followed in a Christian's life), a wide array of issues related to the family life (the sanctity of matrimony; the problem of abortions; family planning; the relationship between generations in the family line) or to pastoral activity (the relationship between a confessor and the young to be guided towards a meaningful life). Through all his efforts in the service of the Romanian Church and nation, Father Arsenie Boca stood out as a distinguished spiritual director, a guide of the souls and a convincing missionary.
\end{abstract}

Keywords: Father Arsenie Boca; religious-moral; spiritual; confessor;

\section{PRELIMINARY CONSIDERATIONS}

Preaching played a major role in safeguarding Orthodoxy in Romania, and in the development of the national language and culture, as note all the treatises of history of Romanian language and literature. Also, sermon preaching is acknowledged as an important factor in maintaining the national consciousness or Romanians on both sides of the Carpathian mountains. Since the content of the sermons mirrored the life of Romanian society at various times, many of the old sermons still surviving are today sources of information for historians, sociologists and philologists, reflecting long gone states of affairs $^{1}$.

$20^{\text {th }}$-century Romanian sermon expressed, even more than the previous centuries, the cultural, social, economic and political challenges faced by our nation. Preaching was comparatively more cultivated in Transylvania, because of the proximity of the Protestant Church where simplified liturgical practices gave prominence to the sermon; this occasioned a true missionary competition among preachers, whose carefully devised sermons were published in the times' journals and in sermon books. Undoubtedly, all diligent preachers produced carefully structured texts, to pursue religious-moral aims and to address the realities of everyday life. One could categorize $20^{\mathrm{th}}$-century preaching into three periods: from the turn of the century to the advent of communism (1945); the communist period proper (1945-1989) and the period 1990-2000, when freedom of expression was gained and

${ }^{1}$ Rev. dr. Nicușor Beldiman, Predica în Biserica Ortodoxă Română din Muntenia în secolul al XX-lea Analiză şi evaluare, Editura Episcopiei Giurgiului, 2013, p. 46. 
exerted $^{2}$. From the $20^{\text {th }}$ century onwards, the Romanian Orthodox Church has had outstanding preachers, erudite theologians and great in the missionary and national realm, whose sermons provided substantial Orthodox theological teachings, full of dogmatic and moral subtlety, which mirrored the authors' insights, beliefs and spiritual experience.

Some of them, aware of their responsibilities and understanding the ,signs of the times", foresaw the dangers of the atheist communism and by their sermons called to the safeguarding of the national-Orthodox consciousness, which later brought them many and various persecutions, including imprisonment, and even death ${ }^{3}$.

\section{A BRIEF PORTRAIT}

One of these erudite and brilliant preachers of this period was Father Arsenie Boca, who would mainly address the common people as they were the majority of worshippers, as they still are today; however, his words reached even the most aristocratic circles. It was by no royal whim that Princess Ileana invited him to talk before the royal entourage. Most likely, the impression made by Father Arsenie's words contributed to the tonsure into monasticism of Princess Ileana who later became Mother Alexandra. His words have endured through time and reveal to us the luminous entrance into the Kingdom of Heaven.

A great spiritual director of last century's Romania, an unforgettable figure for those who knew him as a „unique phenomenon in the history of Romanian monasticism”, Zian Boca (the Father's lay name) was born to a Transylvanian couple: Iosif and Cristina, in late September 1910. He attended the primary school in his native village, then became a student of the Orthodox High School „Avram Iancu” in Brad, established by the worthy of remembrance metropolitan of Transylvania, Saint Andrei Şaguna, and graduated with honors ${ }^{4}$. On 10 May 1929, in the courtyard of „Avram Iancu” highschool in Brad, the valedictorian of that year's class - Zian Boca, planted a durmast oak which was by unanimous decision named ,Zian's Oak”. The man born in the heart of Transylvania, at Vaţa de Jos, close to Țebea, where „Horea's Oak” stands, was then performing a symbolic act, which reveals its full significance only today; not far from the durmast oak of the great martyr of our history, was planted another durmast oak by the one who would later become, by the monastic name Arsenie, the great charismatic confessor of our ancestral faith, at odds with his ,,crazy century"

He studied Theology and Fine Arts, but also passionately attended courses of Medicine, then became a celibate deacon in 1935, and in 1939 he set off for the Holy Mount Athos, where he lived ascetically for three months in preparation for monastic life. There, it is said that he encountered a very demanding, very strict elder who scolded him: ,You are good for nothing, not even sweeping the floors!”, and his reaction was: „I have found the right elder!". From a very young age he demonstrated the ascetical calling which he would later declare to be fiery: „Not all those living in the world are lost, and not all those living in a monastery are saved... Some monks are not true monks, but merely clothes hangers for the monastic habit... If you want to be a monk, then you must burn like fire!".

\footnotetext{
${ }^{2}$ Rev. dr. Nicușor Beldiman, Predica în Biserica Ortodoxă Română din Muntenia în secolul al XX-lea Analiză și evaluare, p. 46.

${ }^{3}$ Rev. dr. Nicușor Beldiman, Predica în Biserica Ortodoxă Română ...., p. 47.

${ }^{4}$ Vasile Manea, Preoți ortodocși în inchisorile comuniste, ediţia a II-a, revăzută și adăugită, Editura Patmos, 2001, p. 52.

${ }^{5}$ Dan Lucinescu, Părintele Arsenie Boca, un sfânt al zilelor noastre, Editura Siaj, Bucureşti, 2009, p. 10.
} 
According to Father Teofil Părăian, Metropolitan Nicolae Bălan was intent on making Sâmbăta Monastery into an exceptional monastic center, and he set off to achieve this goal by engaging ,three great men” in the effort: Father Arsenie Boca, Father Nicolae Mladin and Father Serafim Popescu. Arsenie Boca joined the restored monastery of Sâmbăta de Sus, in the summer of 1939, and in the next year he was tonsured into monasticism and initiated what was later known as the movement of spiritual revival of Sâmbăta. The tonsure of the young celibate deacon ${ }^{6}$ Zian Boca was generally expected. „Revista Teologică [The Theological Journal]", published at Sibiu, noted that on 3 May 1940 took place the solemn service of tonsuring one of the „enlightened graduates of Academia Andreiana”- the young hierodeacon Arsenie Boca. Known for his integrity of character and his spiritual loftiness, Father Arsenie was ordained a priest on the Friday celebrating the Healing Font of the Mother of God, 1942.

Once the communist regime was installed, which entailed concerted efforts to destroy religious belief in the people's souls and turn them away from the Church of Christ, Father Arsenie became one of the victims of the Secret Services [the Department of State Security „Securitate"]. He was first arrested in 1948, and charged with supporting the anticommunist fighters in Făgăraş Mountains. Both on these charges, and because of his increasing notoriety among the devout Christians, he was inestigated by the political police. As he took a stand against communism, Father Arsenie was expelled from Sâmbăta, sentenced to prison and sent to the forced labor camp at the Danube-Black Sea Canal, where he was an epitome of dignity and offered much support to his fellows. Later, he was forced to move from Sâmbăta Monastery to Prislop ${ }^{7}$, where he became the abbot; after the monastery was turned into a convent, he stayed as a spiritual director and confessor for the nuns, until 1959, when the communist authorities forced the community to leave the convent. In the meanwhile, he had been again arrested and sent to the Canal, where he spent almost a whole year. Later he was sent to Bucharest, under the constant supervision of the political police. During the last part of his life, he was particularly fond of two places: Drăgănescu - in Giurgiu county, where he worked on the local church's painting for 15 years, from 1968, and bequeathed to us a true, and singular, sermon by means of images; and Sinaia, where from 1969, he had his cell and his workshop and where he used to withdraw increasingly often, and where he also died in the early winter of 1989, aged 79 . He was buried under the fir trees of Prislop, the monastery where he had been first exiled by the communist authorities and which ended up by becoming his preferred place ${ }^{8}$.

\section{TOPICAL THEMES AND IDEAS}

Such a personality is very difficult to describe by means of words; whatever one might say is too little, insufficiently relevant. The Father did not speak much, but his sermons were substantial. When he delivered more extensive sermons, at Sâmbăta Monastery, not everyone was able to understand him. However today, more than 60 years later, his writings demonstrate the topicality and relevance of his teachings. His writings especially Vreau să schimb lacrimile voastre în bucurie. Antologie de cuvinte duhovniceşti ale Father Arsenie Boca [I Want to Turn Your Tears Into Joy. An Anthology of Spiritual Teachings of Father Arsenie Boca $]^{9}$ contain several extremely topical themes, as he

\footnotetext{
${ }^{6}$ Dan Lucinescu, Părintele Arsenie Boca, un sfânt al zilelor noastre, p. 11.

${ }^{7}$ Florin Duţu, Părintele Arsenie Boca - o biografie - , Editura Floare Albă de Colţ, Bucureşti, 2014, p. 55.

${ }^{8}$ Dan Lucinescu, Părintele Arsenie Boca, un sfânt al zilelor noastre, p. 11.

${ }^{9}$ Editura „Agaton”, Făgăraş, 2014.
} 
addressed various aspects - and provided true lessons - of medicine, family life, monasticism, Church life, and so on.

Self-righteousness is a conceited, ,holier-than-thou” attitude by which a person attempts to gain social recognition, without taking into account and showing any concern for the others' needs and expectations, but considering one's own ego to be strong and mature enough to dominate and control the social mechanisms within a group or a social environment ${ }^{10}$. Moreover, self-righteousness creates the illusion that everything is going your way, that you do not depend on anyone and anything; sometimes the closest persons begin to bother you, and you perceive yourself as a little ,god" on which they rely or whom they should worship, etc. ,When you fall into self-righteousness, you have closed all doors to self-improvement. When you are aware of your shortcomings and imperfections, then this proves that the Perfect One is beside you - and your conscience, the eye contemplating heavenly things, proclaims the difference between Him and you"

About abortions, Father Arsenie shows it is a capital sin. It is „,murder, nothing less. Listen carefully, everyone: the blood that has been shed calls to be avenged. Also, you will not have joys from your other children, but only sorrow. The punishment for bloodshed is merciless: either God takes away from you your other children too, or the mother herself is punished. Many mothers die even during their abortions. Or they have some other trouble, lose their heads and forget about the great mercy of God shown for all sinners, and the devil approaches them and makes them despair and even commit suicide.

Great trouble afflicts the mothers who kill their own children. And if you want to be saved, together with your other children, you must take in your care the same number of children as the aborted ones, from poor families, and have them baptized becoming their godmother - or even care for other children, already baptized. Care for them as for your own children, provide them with clothes, shoes, food, school fees, until they are able to earn their own living; offer them the same education as you give your own children. And all the troubles you might face during this time, be they from them or for their sake, accept and endure everything, trusting that the merciful God will forgive you for your sin, for in patience lies atonement for sin. Almsgiving and repentance outweigh the just punishment.

Teach other young women not to do the same as you have done, for you know how deeply you regret it. Abortion is worse than ordinary murder, because it is committed against a defenseless child. This is why it calls for the life of both mother and father. The children's blood cries out to Heaven to be avenged, and few go unpunished. The disasters, the wars, bring the just punishment where there has been no repentance.

Therefore, repent and stop sinning! Run to the church, confess sincerely and receive the Holy Eucharist, because it is the only way to earn the protection of God for yourselves and your homes. Never forget, fasting is the gate and confession is the door. They bring about the protection of God, without which we are unable to achieve anything. „I said, I will confess my transgressions unto the Lord; and thou forgavest the iniquity of my sin" (Psalm 31/32). We deserve punishment for our sins, so we must atone for them and cease to do them. „For this shall every one that is godly pray unto thee: surely in the floods of great waters they shall not come nigh unto him". See how our minds, hearts and bodies must be:

\footnotetext{
${ }^{10}$ Rev. Arsenie Boca, Cărarea Împărăției, Editura Episcopiei Ortodoxe Române a Aradului, Arad, 1995, p. 22.

${ }^{11}$ Vreau să schimb lacrimile voastre în bucurie. Antologie de cuvinte duhovniceşti ale Părintelui Arsenie Boca, Ediție îngrijită de Natalia Corlean, Editura Agaton, Făgăraș, 2014, p. 22.
} 
cleansed and purified, for God will not protect a defiled body and perverted heart and mind, and if we make amends our days will improve and and we will find our joy"12.

Attitude towards life. Analysts of contemporary life have described youth as "The ME Generation", a very appropriate term for today's culture of narcissism, with its fascination with the self, which hinders a normal development of the human being. Others speak of the artificial universe or the virtual world of fantasy in which many people live now, unable to face or understand the reality of the surrounding world or their own problems ${ }^{13}$. Regarding these attitudes, Father Arsenie asserts that by our very nature we belong to the physical and the metaphysical realms at the same time. As such, we can survive without bread for a while, but we cannot live without an outlook on life. If we confine our origins and ultimate destiny to the physical realm, then a number of issues remain unaddressed and unsolved, we live immersed in secondary truths, whereas the fundamental Truth itself remains inaccessible to us ${ }^{14}$.

One's attitude towards life has to integrate body and soul. This modifies in a positive way the structure of the cells in the entire body, harmonizing it and remedying the damage caused by pain and suffering ${ }^{15}$. The cause of ,,man's disfigurement lies in the wrong belief that happiness can be found in the earthly things. One must live in the world, but always above the world. Do not impoverish the meaning of life, reducing it to worldly pursuits! Achieve them, but always be above them! Because of the instability and transience of things, because of the conflicts with the world's meanness and infirmity, one must anchor one's life in God who never lies, as does the earthly world. The only knowledge that is free of error and relativity, is God's as He is the Absolute, the beginning and the end of the world. He is the only One who turns chaos into cosmos. When one entrusts oneself to the divine Providence, out of love for God, then that person overcomes the human condition freely and deliberately - of course, with the support of God's grace - and can receive even in this life the foretaste of perfection, perceived as a sense of freedom, as a resurrection. Time, causality, the world, life and all human knowledge, so full of tormenting contradictions, fall behind like an egg shell after the bird has hatched, or like that instant when a hairy caterpillar - after the apparent death of a chrysalis - morphs into a rainbow-colored butterfly. In this life, man is like a vigil lamp, filled with oil and equipped with a wick, but still unlit. Once we become aware of what we really are, of the fact that we are always related to God, that God dwells in our spiritual structure, that we are called to make a free choice and opt for an attitude towards life, which we adhere to even if those around are against us, then God kindles the vigil lamp and enlightens our whole life with the Christian view on world and life" 16 . Generally, the Christian attitude is not taken to the ultimate level even by the devout people, and not even by those familiar with theology, but a great amount of selfishness is retained and very much ,alive”. In other words, there are very few human beings who „risk” their whole life, putting everything at stake for the sake of God, fighting for the cause of God in the world. This, however, demonstrates only the human weakness - due to the disease of egotism - and not the weakness of Christianity, as value of light of life ${ }^{17}$.

\footnotetext{
${ }^{12}$ Vreau să schimb lacrimile voastre în bucurie. Antologie de cuvinte duhovniceşti ale Părintelui Arsenie Boca, p. 23.

${ }^{13}$ Rev. Arsenie Boca, Cuvinte vii, Deva, 2006, p. 21.

${ }^{14}$ Vreau să schimb lacrimile voastre în bucurie, p. 43.

${ }^{15}$ Rev. Arsenie Boca, Cărarea Impărăției, p. 47.

${ }^{16}$ Vreau să schimb lacrimile voastre în bucurie. p. 43.

${ }^{17}$ Vreau să schimb lacrimile voastre în bucurie., p. 43.
} 
„The religious outlook on life must be deeply entrenched in one's thinking and vocabulary; many are ashamed of their poverty of their religious life, and even when they do try their best, they find that their religious terminology dates from the time of their childhood"18.

Decision making. The way in which we make decisions in our daily life, from the most commonplace ones to the very important ones, greatly depends on each person's education, circle of friends and social milieu, and degree of intelligence. In order to make the best possible decisions, each one must know oneself, and also possess a certain degree of intelligence. In making decisions, we refer to our past experiences. Father Arsenie considers that the best helper is that one which prompts you to make your own decision and take responsibility, not the one who decides for you. Why? Because, whatever direction you take, you will encounter unexpected difficulties, obstacles, adversities, temptations, trials and tribulations, and so on; and then you will lay the blame on the one who ,helped" you make the wrong decision ${ }^{19}$.

A good helper ,,is the one who offers you the best knowledge of things and prompts you to the best self-knowledge, so that you can make an informed decision for yourself. The best decision is that one which is good under any circumstances and at any age. Thus, a good decision is the one which corresponds to your actual power to follow it without hesitation, without compromise and with undiminished joy, all your life long. Difficulties are certain to appear, and the bolder and loftier your decision, the harsher the obstacles. And if your power is not really up to the task, then you come to truly know yourself belatedly, because you have followed an illusion and deceived yourself, instead of discerning your real possibilities. You see, people may change their minds from one day to the next, from one event to the next, sometimes for no serious reason at all. And there are decisions that require constant progress, along an ascending line; because we are called to grow not only biologically, but also spiritually, as we meet the challenges of life and as we mature. Defeats can be beneficial, when they reveal to us our own shortcomings and make us humbler, when we start again setting more modest goals - but we do start again. On the other hand, they can also be detrimental, when we lose faith in the power of good and allow ourselves to become discouraged" 20 .

Balance. The concept of „balance” is individual, personal, and not a universal constant which can be measured, corrected and maintained at an optimal level, once it has reached that level. On the contrary, it varies according to each one's individual personality, context or expectations. Father Arsenie pointed out that ,evil, madness, chaos, are not literature: they are realities which sometimes strike with full force and upset your precarious balance. Sometimes you find yourself in such a situation, that clearly only God can make you overcome the difficulties. The invisible order of things invites us to bring into the luminous sphere of consciousness, the latent potentialities of our being: once they are brought to actuality, they exceed in beauty and force everything we had acquired that far. Through their intrinsic beauty and force, they restore our peace of mind and our balance, which our human reason - however muchwe train it by means of science or philosophy could never regain on their own. In physics, the balance of an object is ensured only if the vertical line drawn from its center of mass falls within the area of its base of support; similarly, one's understanding of life, one's intellectual horizon is one's base of support.

\footnotetext{
${ }^{18}$ Vreau să schimb lacrimile voastre în bucurie., p. 43.

${ }^{19}$ Vreau să schimb lacrimile voastre în bucurie. p. 58.

${ }^{20}$ Vreau să schimb lacrimile voastre în bucurie. p. 58.
} 
You must be aware of your own „center”, you must know yourself and must also be aware of the process of change and becoming you need, in otherwords to become centred, and so achieve balance, ${ }^{, 21}$.

The family is the oldest Christian establishment. No other institution plays such a decisive role for man and society, as the family institution. If the family is grounded in a healthy set of values, then the entire society can progress. Otherwise, everything falls apart. The fact that Jesus attended a wedding together with His disciples (John 2,2) proves that the wedding is the first divine miracle performed for the good of mankind; matrimony prevents the human nature from taking a wrong path. That is why the wedding is elevated to the rank of Holy Mystery, one of the seven Mysteries, precisely so that people may understand this and depart from lust and self-indulgence ${ }^{22}$. Speaking about the Christian family, Father Arsenie Boca attaches great importance to the topic of matrimony, stating that „Christ has elevated marriage to the rank of a Holy Mystery. If the value and sacredness of matrimony is understood and lived by the spouses as a Mystery, then it can also carry fruit worthy of the Mysteries of God. Why does God scold people because righteous men are no longer born, and people ignore this? The answer is the following: the righteous are instruments of God, through them He directs the people and through them is His mercy manifest; if there are no righteous ones, then people will be rewarded according to His justice, each for their deeds. If the family is burdened by iniquity, then people are held responsible and they face the same punishment as the barren fig tree. When the family ceases to be grounded in the Mystery, then people will be like packs of debauched wild beasts" ${ }^{23}$.

Father Arsenie saw family as the first and most important school of moral behavior. The dominant state of soul in the family, ,especially the mother's and especially during the pregnancy, will be characteristic for the entire life the offsprings". The family is threatened by a crisis. Some proclaim „casual sex”, without any commitment or responsibilities; others are discouraged, as they witness the self-destruction of this institution. The fruit of marital love is the child, who is the expression of the „divine intention”, as Father Arsenie Boca puts it. The spouses do not merely collaborate with each other in their marriage; they collaborate with God here on earth, as they pursue the goal for which God has instituted matrimony. Because it is a Church Mystery, marriage must always be regarded as holy, the Father says. Through all its Mysteries, ,the Church acknowledges and sanctifies all aspects and functions of human life", so that living according to „the spiritual sense of Matrimony” can be pursued by all those married in the Church. Obedience to God makes a marriage durable and acceptable to Him. No progress can be obtained without self-control and without the sense of responsibility for the family" ${ }^{24}$.

True freedom. God respects the freedom which He Himself has granted to us. In creating the man, God made a free being, not a machine. The people, unlike plants and animals, enjoy this great divine gift: we have the ability to direct ourselves, according to our own free will and conscience, according to the lofty commandments coming from within us. Father Arsenie categorically states that God does not want to enforce His will; he wants no worship coming from mere puppets. Instead, he wants to be worshipped out of man's free will. Even when man turns his freedom against God, He still allows that freedom to man and does not deny it. „On the threshold of human sol, God suspends His dominion, because $\mathrm{He}$

\footnotetext{
${ }^{21}$ Vreau să schimb lacrimile voastre $\hat{\imath}$ bucurie. p. 81.

${ }^{22}$ Vreau să schimb lacrimile voastre în bucurie. p. 90.

${ }^{23}$ Vreau să schimb lacrimile voastre $\hat{\imath} n$ bucurie. p. 90.

${ }^{24}$ Vreau să schimb lacrimile voastre în bucurie. p. 90.
} 
seeks man's friendship. Here, in man's soul, God wants to be received at man's initiative. Freedom of conscience is a special gift granted to man, so that through it man may progress and reach perfection. But the same gift also enables man to go against God, leaving some with the impression that there is no God, but they are ,gods". At this point, freedom is lost and man falls into chaos, in ,sinning against the Holy Spirit”. People have become slaves of their passions. In the case of this bondage caused by passions, the control of the mind is considerably weakened and the passions govern man's mind, and so man loses his freedom" 25 .

Christianity was the first to make people aware of their liberty. Freedom is a great gift, exceptionally great. However, the very magnitude of this gift of freedom can be detrimental if man uses it to do evil, because then he is no longer free, but a slave. Freedom can lead to salvation only if if passes through sacrifice. Self-sacrifice is the test. A man becomes truly free only if he renounces everything and especially himself. Through Baptism we are freed from the bondage of sin. The New Testament commandments are the commandments of freedom, commandments of the grace, not commandments of the law. However, if we fail to obey them, we lose our freedom again. Compliance with the New Testament commandments ensures the freedom of the spirit, while failure to complain returns us under the tyranny of $\sin$. In the religious realm, freedom is not an abstract notion, as it is in sciences; here, it is ingrained in the structure of the spiritualized man, who is in possession of the truth even in this earthly life. Such a man, even if he remains silent, testifies before his fellow people about Jesus, who has set him free ${ }^{26}$.

Divine power is self-evident and „,needs no further demonstration. However, we see that lack of faith hinders people from perceiving it as obvious. Consequently, faith is a decision made in free will. Because only man's freedom sets a limit (only up to a point) to God's omnipotence. The decision to believe in God, or the decision to be an atheist, is an act of freedom - in the positive, respectively the negative sense of freedom. Jesus appeared to lack power; actually, He chose not to manifest His omnipotence and His glory, which $\mathrm{He}$ will only on His second coming, when the negative decisions made by human freedom will no longer be accepted. Those who fail to renounce their own egos, cannot be free. The whole world is yours once you have given it up. Then you are stronger than the world, and the world obeys you"27.

Idleness. Father Arsenie's sermons do not only preach virtues, but also fight against this sin, which is very detrimental to the religious-moral and social life of the faithful. The author points out that the life of our Saviour sets the most beautiful example of a life spent working. It sets an example also by the fact that everything is given due measure. Today, we find that ,,idleness, comfortable life, pleasures, honors, will never lead us to God. We fail to find God, because we are not obssessed with this, we are too complacent in our sordid lives, too satisfied with our flesh, and we have not vowed to break with these banal ways" 28 .

Work brings to the true Christian the satisfaction of ensuring the happiness of loved ones, the possibility to educate and raise children in obedience to God, and to do good to the fellow people, and thus to gain the salvation of soul. By working, a Christian can do such deeds that are acceptable to God and able to ensure the happiness for both himself and his descendants. In contrast, idleness ,,makes the soul weak and forgetful; unable to undertake

\footnotetext{
${ }^{25}$ Vreau să schimb lacrimile voastre în bucurie. p. 141.

${ }^{26}$ Vreau să schimb lacrimile voastre în bucurie. p. 141.

${ }^{27}$ Vreau să schimb lacrimile voastre în bucurie. p. 141.

${ }^{28}$ Vreau să schimb lacrimile voastre în bucurie. p. 140.
} 
any effort, incapable of obeying God and complacent. Lazy, idle souls do not free themselves from passions, and do not raise above the earthly matters. Idleness is the climate in which passions thrive; the body is weakened and the soul is impoverished. More and more other passions develop, distract and pervert the mind" 29 .

The family line. Our present has been the future of a past - our own past, or that of our ancestors. In the present, we meet the future of the past; often, it is the result of ancestral past, comprising many generations. Vices, especially alcoholism and debauchery, cause the degenerescence of the descendants. When a man dies, his weaknesses are passed down to his descendants, who have to fight against them. If they succeed in overcoming them, then their victory also helps the soul of the one who has died. When a man fights against ,his weaknesses" and overcomes them, with God's help, then an endless number of his ancestors rejoice, too. Such victories are the strongest prayers we can make for the sake of our beloved deceased $^{30}$. This action of God, ,by which people control their deeds because of their have consequences, is called atonement. Atonement is God watching over the individual destiny and the destiny of a family line. Evil-doing is punished through its own consequences, but divine love still offers a way to obtain forgiveness, provided that one member of that family does what is good before God. Those with a wicked life, when God decides to punish them, cannot be defended by anything, wherever they may be; however, those who lead a pure life are protected by God Himself, better than any defense of the world. The family lines have a destiny which is known to God. When they follow their destiny, they have God's protection; when they betray it, the punishment follows" 31 .

Family planning. Pointing out that people who marry must bring new people into the world, just as those who join the army must learn how to use weapons, Father Arsenie opposes the erroneous idea of family planning, considering that a Christian family ought to produce children. The topic is as relevant as ever, for just as the role of school is to impart knowledge, the role of courts is to impart justice, similarly the role of the family is to impart new life by having children. There are also couples which cannot procreate, and this is God's will. Those who believe in God and His providence should resign themselves, overcome their sorrow and adopt orphaned children, or do acts of mercy to those deprived and unloved. There are, however, countless other cases of spouses who refuse to become parents. They perform the life-giving act, but reject its natural consequences. They taste the pleasure, but shun responsibilities. Some do not want to have even one child. They marry for various reasons: pleasure, vainglory, wealth, the intention to join two dowries, the desire to bear a particular name, or to be safe in old age. There are many causes for the refusal to have children. First, there is the modern man's pursuit of pleasures. Having and raising children involves many efforts, forces the parents to give up many things. They can hardly rest, they sleep badly. They must work harder, in order to provide for several others; they must renounce expensive clothes in order to dress their children instead. People want to enjoy themselves, to party, to travel, to afford luxuries. „You, just starting married life, may be tempted to think that you are too young to start having children from the first year of marriage; you might want to enjoy life for a while, and start a family later. If you accept this idea, you pave the way to sinning and to a suite of troubles which are bound to follow. To avoid taking a wrong path, you should from the very beginning adopt the right position

\footnotetext{
${ }^{29}$ Vreau să schimb lacrimile voastre în bucurie. p. 140.

${ }^{30}$ Vreau să schimb lacrimile voastre în bucurie. p. 161.

${ }^{31}$ Vreau să schimb lacrimile voastre în bucurie.p. 161.
} 
concerning children - the fruit of marriage, blessed by the Church. Children are the fruit of love; rejecting them is not love, but a crime. Seeking only pleasure, and avoiding the natural function of the instinct, is a vice and a sin and is punished by the all-seeing Law. So, if you are not determined to start on the right path from the very beginning, you will very easily make mistakes in your life together, and these mistakes will bring about trouble and problems which are inevitable. Divorce does not remedy any mistakes. Their consequences affect your later marriages and your later life, whatever you do. Not even prayers can help. Only the Holy Confession makes you aware of your transgressions of the Law given by Matrimony, and provides God's forgiveness for your ignorance (if you have erred from ignorance), or for your weakness (if this has been the cause) and also gives you the power to make atonement, if you mend your ways. God forgives you (if you pray for forgiveness through Confession), but nothing can go unpunished and without atonement" ${ }^{, 32}$.

Rules for the Christian life. The author notes that man always wants to find happiness in himself, in the love for oneself - which is but a shadow of the true love, instead of seeking happiness in God and His love, which is the only true and lasting one. Some believe that self-indulgence, passions, lust, debauchery, are the best way to happiness. However, self-deceit is as great as the pleasure obtained, because man believes he has found happiness while it actually eludes him. Man finds that what he has is nothing, compared to what he wants to have. This is why whoever seeks happiness in himself, will never find $\mathrm{it}^{33}$. Our life depends on the goals we set for ourselves to attain. As your goal is, so your life will be. As the spring is, so is the water coming forth. If the spring is clean, then the water is pure as crystal. If, however, the spring is muddy, then the water flows dirty, as the mire in which man sinks. True life is not that lived according to the body, not the life governed by the pleasures of the body and the satisfactions of this world, because we are made of both body and soul. The true life is that lived according to the soul, which is much loftier, much more beautiful, much richer than bodily life.

Based on these realities, Father Arsenie says: „Would you like to see your inward sun rising on the sky of your life? Then try to examine your own conscience every night, make prostrations, read a psalm, say a prayer, all in humility, easing the burden of your soul and gaining more and more love for your fellow people. Live every day in self-awareness - you will gain courage and will feel that the divine grace is working with you. Human life is like a furrow made by a plough. So strive to make your own life into a straight furrow; remove any mistakes, any deviations from the right path; correct your furrow before darkness and frost come, by doing all the good you can do, as long as the plough of your soul is still able to work upon your life. Under the guidance of a clean conscience and with the mercy of our Great God, always remember how good in the sight of God are the peacemakers. To reach God you need not travel near or far, because He is everywhere and closer to you than your very own body and soul - all you need is awareness of this, through faith and a prayerful state. The Lord is near all those who cry out to Him with all their heart" ${ }^{34}$. Those who worship their bodies are present for this world, and absent for the rest of the world. In contrast, as Father Arsenie shows, the others understand that spiritual life is not only a joy but actually a highly precious God-given gift; precisely because it is a gift, we must cultivate it carefully. People who do so are aware that the world is transient and deceitful and that putting all your hopes and expectations into it is tantamount to dying - not only here in this

\footnotetext{
${ }^{32}$ Vreau să schimb lacrimile voastre în bucurie. p. 174.

${ }^{33}$ Rev. Arsenie Boca, Cuvinte vii, p. 157.

${ }^{34}$ Vreau să schimb lacrimile voastre în bucurie. p. 203.
} 
world, but also in the world to come: ,When you awake in the morning, think that God is offering you a day which you could not offer to yourself by your own powers, and set apart the first hour of the day or at least one quarter of this hour, and give it as a sacrifice to God by prayers of thanksgiving and petition, asking for the good things. The more you do this, the more you will sanctify you day, the more protected you will be from the temptations you face during that day. The morning prayer is like the morning dew for the plants. Whoever prays to God in the morning, with due attention, will be more peaceful and more serene for the rest of the day. God does not expect miracles from our part. He is the one who works miracles. God simply asks us to live our lives as the Gospel teaches us to, live in acordance with it. This is the miracle He requires from us. All the rest are His work. If so, then why is there so little faith on the earth? One explanation is that very few lives are offered to God: very few people give Jesus absolute authority on their lives; and they are not hindered by any difficulty or fear, but by love for themselves, which grows like a weed in the soil of life. Begin and end your day with God. The most beautiful gift we can offer God is ourselves, and our whole lives. Do not hope to receive Heaven for free, without living a life worthy of Heaven, 35 .

Young age. The Church cannot be unresponsive to the challenges of today's world, because its mission lies precisely in proclaiming the Gospel of Christ's merciful love for the world, and preaching the way of life in compliance with this Gospel. Father Arsenie addresses the young people of all times, quoting the wisdom of thinkers and the lives of the Holy Fathers: Young age sets the foundation for the rest of man's life. God forgives ignorance, but not cunningness. And a cunning person is that who gives his youth to the devil, and offers to God only his wrecked old age. Will not such old age be rejected, just like the wicked youth? If you give your youth to the devil, you shall see it has been a wrong choice. But will you still have enough days to live, to offer them to God? And will He accept shreds and broken pieces, instead of the whole life? These words are harsh, yet this is the answer to the question: why do people fail to come to Confession in the spring and summer of their lives? They offer the prime of their lives to the serpent! Young age believes that it can beguile God, leaving Him only the old age. But will you even reach old age, and will such wrecked pile of shreds be able to repent and become acceptable? Those who postpone repentance and put it off till old age, are like the people who want to cross a river, but wait on the river bank for all the water to flow away. Most people fall into this trap"36.

As spiritual parents, the priests must be concerned with the spiritual growth of children and the youth. In young age, every person experiences a great urge for giving and receiving love, a strong desire to live a meaningful life. The Church must be attentive and care for the needs of the young. Often they face fear, disappointment, loss of love, are wounded and mistrust their fellow people, have difficulties in communicating with their parents and teachers. They thirst for authenticity and for the essential truths.

They long for such spiritual guidance that can teach them how to live in loving communion, and can bring meaning into their present and future life. Father Arsenie points out that ,the young people seek pleasure, rather than denying it. Who can be safe from all its traps? Only those who are practicing Christians, living according to the teachings of the Church. The religious outlook on life must be deeply entrenched in one's thinking and vocabulary; many are ashamed of their poverty of their religious life, and even when they do try their best, they find that their religious terminology dates from the time of their

${ }^{35}$ Vreau să schimb lacrimile voastre în bucurie.p. 203.

${ }^{36}$ Vreau să schimb lacrimile voastre în bucurie. p. 257. 
childhood" ${ }^{\prime 37}$. In response to young people's enthusiasm, the spiritual director must be open and friendly, sensitive to their needs and inquiries, and above all he must demonstrate a sacrificial spirit, patience and generosity: „As in all fields, in the realm of the faith there is a practical and an abstract aspect. Mistakes can be made on both levels, but they can be corrected. In order to learn the tenets of the faith and put them into practice in everyday life, one needs to choose a spiritual director. This appellation derives from Spirit - the Holy Spirit: a spiritual director is a man who regards life in a different spirit than that of flesh and earthly things. This understanding of life, according to the Spirit of God, cannot be derived from mere readings or from attending the Church services, but only by becoming an earnest disciple of a director with rich spiritual life. His role is extremely important for our soul. Our confessors, or spiritual directors, have been granted the power to forgive and heal our failures, our moral defeats. They can bring peace to our souls and help us overcome crises. However, as the option for pleasure, „chosen” as a life principle, opens the path to moral decay and as all spiritual directors strive to free the human soul from this bondage, this is the reason why many young people do not go to the confessor ${ }^{38}$.

\section{CONCLUSIONS}

An outstanding personality among the $20^{\text {th }}$-century Romanian preachers, Father Arsenie Boca was a charismatic speaker. A priest endowed with great persuasive power, he was a fearless defender of the ancestral faith, and of the Christian ideal, against the atheism championed by the communist authorities, falling victim to their persecutions. The literary style of his sermons is characteristic: concise, eloquent sentences, a vocabulary both refined and understandable, a straightforward manner of addressing his audience, creating the impression of a dialogue with his listeners. The writings of Father Arsenie Boca prove him to be a master of the perlocutionary act, especially in the concise and memorable form of the so-called ,chapters". Responsive to all the great aspirations of his times, and the major concerns of his epoch, Father Arsenie endeavored to provide answers to the great problems of life, based on the Christian teachings, in order to elevate and infuse with morality the society he belonged to. Through all his efforts in the service of the Romanian Church and nation, he stood out as a distinguished spiritual director, a guide of the souls and a convincing missionary.

\section{BIBLIOGRAPHY:}

[1] Beldiman, Nicuşor, Predica în Biserica Ortodoxă Română din Muntenia în secolul al XX-lea Analiză și evaluare, Editura Episcopiei Giurgiului, 2013.

[2] Boca, Arsenie, Cărarea Împărăției, Editura Episcopiei Ortodoxe Române a Aradului, Arad, 1995.

[3] Boca, Arsenie, Cărarea Împărăției, Editura Episcopiei Ortodoxe Române a Aradului, Arad, 1995.

[4] Duţu, Florin, Părintele Arsenie Boca - o biografie -, Editura Floare Albă de Colţ, Bucureşti, 2014.

[5] Lucinescu, Dan, Părintele Arsenie Boca, un sfânt al zilelor noastre, Editura Siaj, Bucureşti, 2009.

[6] Manea, Vasile, Preoți ortodocşi în inchisorile comuniste, ediția a II-a, revăzută și adăugită, Editura Patmos, 2001.

[7] ***Vreau să schimb lacrimile voastre în bucurie. Antologie de cuvinte duhovniceşti ale Părintelui Arsenie Boca, Ediție îngrijită de Natalia Corlean, Editura Agaton, Făgăraş, 2014.

\footnotetext{
${ }^{37}$ Vreau să schimb lacrimile voastre în bucurie. p. 257.

${ }^{38}$ Vreau să schimb lacrimile voastre în bucurie. p. 257.
} 